\title{
The Use of the Health Technology Assessment for Technology Acquisition in Hospitals
}

\author{
S.P. Usaquén-Perilla ${ }^{1}$, A. Cano-Muñoz ${ }^{1}$, D.M. Troncoso ${ }^{1}$, N Bonilla ${ }^{1}$, R.T. de Almeida ${ }^{2}$ \\ ${ }^{1}$ Grupo de investigación en Ingeniería Electrónica Industrial y Ambiental GIEIAM, Cali, Colombia \\ ${ }^{2}$ Programa de Ingeniería Biomédica/COPPE, Universidade Federal do Rio de Janeiro, \\ Rio de Janeiro, Brasil
}

\begin{abstract}
Decision makers at the national and local level of health systems require evidence of effectiveness, safety and costs of health technologies for resource allocation. In this sense Health Technology Assessment (HTA) is a favorable tool considering it is a multidisciplinary process to evaluate the benefits as well as the social, economic, organizational and ethical issues of a health technology. The aim of this study was to review the literature in order to identify the attributes used in the process of technology acquisition. It was analyzed the attributes of HTA with the purpose of classifying them, to see which are the most recommended for acquisition in hospitals. The identified literature indicated that not only the clinical and economic attributes were considered, but also attributes related to the context of the hospital such as the effect of technology on other hospital services and others associated with the organization.
\end{abstract}

Keywords - Attributes of health technology assessment (HTA), acquisition in hospitals, health care technologies.

\section{El uso de la Evaluación de Tecnologías en Salud para la adquisición DE TECNOLOGÍA EN HOSPITALES}

\footnotetext{
Resumen - Los tomadores de decisiones a nivel nacional y local de los sistemas de salud requieren evidencia de la efectividad, seguridad y costos de las tecnologías de la salud para la asignación de recursos. En este sentido, la Evaluación de la Tecnología de la Salud (HTA, por sus siglas en inglés) es una herramienta favorable considerando que es un proceso multidisciplinario para evaluar los beneficios, así como las cuestiones sociales, económicas, organizativas y éticas de una tecnología de la salud. El objetivo de este estudio fue revisar la literatura con el fin de identificar los atributos utilizados en el proceso de adquisición de tecnología. Se analizaron los atributos de HTA con el fin de clasificarlos, para ver cuáles son los más recomendados para adquisición en hospitales. La literatura identificada indicó que no sólo se consideraron los atributos clínicos y económicos, sino también atributos relacionados con el contexto del hospital como el efecto de la tecnología en otros servicios hospitalarios y otros asociados con la organización.
}

Palabras clave - Atributos de la evaluación de tecnología de salud (HTA), adquisición en hospitales, tecnologías de atención de la salud.

\% Author's Mailing Address: sandrausaquen@gmail.com

DOI: https://doi.org/10.24050/19099762.n21.2017.1169 


\title{
O uso da Avaliação de TeCnOlogia de saúde Para A AQuisição de TECNOLOGIA EM HOSPITAIS
}

\begin{abstract}
Resumo - Os tomadores de decisões a nível nacional e local dos sistemas de saúde requerem evidência da efetividade, segurança e custos das tecnologias de saúde para a atribuição de recursos. Neste sentido, a Avaliação da Tecnologia da Saúde (HTA) é uma ferramenta favorável considerando que é um processo multidisciplinar para avaliar os benefícios, bem como as questões sociais, económicas, organizativas e éticas de uma tecnologia da saúde. O objetivo deste estudo foi revisar a literatura com o fim de identificar os atributos utilizados no processo de aquisição de tecnologia. Analisaram-se os atributos de HTA com o fim de classificá-los, para ver quais são os mais recomendados para aquisição em Hospitais. A literatura identificada indicou que não só se consideraram os atributos clínicos e económicos, assim como também alguns atributos relacionados com o contexto do hospital como o efeito da tecnologia em outros serviços hospitalários e outros associados com a organização.
\end{abstract}

Palavras-chave - Atributos da avaliação de tecnologia de saúde (HTA), aquisição em hospitais, tecnologias de atenção da saúde.

\section{INTRODUCTION}

$T_{\text {the }}^{\mathrm{h}}$ he Health Technology Assessment (HTA) is the process of analysis and research, aimed at estimating the relative value and contribution of each health technology to the improvement of individual and collective health, taking into account its economic and social impact [1]. The HTA is characterized by a clear formulation of the problem, an explicit methodology and a wide scope of the dimensions to be assessed [2].

The goals of health technology assessment are to [3]:

- estimate the need for health technologies given the health needs of the community;

- assess the safety, efficacy and effectiveness of health care technologies;

- identify the resources required to offer technologies where they will be most accessible to the community members requiring them;

- evaluate the costs and consequences of providing health technology and of not adopting them;

- develop implementation and evaluation plans for the technologies for which resources are allocated

The financial constraints of governments, the rapid pace of production of new technologies and their high cost, have often led to the inefficient incorporation of technology into the health system. So as to achieve the adequate incorporation, different initiatives have been developed, for example the institutions that carry out HTA. In Europe (2004), the European Commission and the Council of Ministers recognized the need for an HTA network with all institutions and health agencies [4]. Nonetheless, it was only until 2006 that the EUnetHTA project was established. This was born in collaboration and funding from the EU and the OECD (Organization for Economic Co-operation and Development). The
EUnetHTA is a collaborative network of HTA agencies for the exchange of information on important emerging new drugs, devices, procedures, processes, and settings in health care [5]. Different projects have been developed, for example: Joint Action 1 (2010-2012): which included work on the relative effectiveness of pharmaceuticals. Joint Action 2 (2012-2015): whose objectives were: to reinforce the application of tools for crossborder HTA collaboration; Achieve collaboration at a higher level to establish a sustainable structure for the EU HTA [6].

In Austria, The Ludwig Boltzmann Institute for Health Technology Assessment (LBI-HTA) was founded in April 2006 for a duration of 7 years, but it was prolonged until 2020 [7]. In Spain, the Agency for Health Technologies Assessment of Andalusia (AETSA) was created by the Government in 1996. The agency develops clinical practice guidelines and evidence-based recommendations, and methodological documents that guide the community dedicated to the evaluation of health technologies, which may also be useful for evaluation in health centers and the research community in health services. AETSA is a member of the (EUnetHTA) [8].The National Institute for Health and Care Excellence (NICE) in United Kingdom, provides national guidance and advice to improve health and social care, NICE guidelines make evidence-based recommendations on a wide range of topics, from preventing and managing specific conditions, improving health and managing medicines in different settings, to providing social care to adults and children, and planning broader services and interventions to improve the health of communities [9].

In United States stands out the Agency for Research and Quality in Health (AHRQ), this agency develops three external research networks: evidence-based center for education and therapeutic research and the program for the development of evidence for decision-making based on effectiveness. Although the FDA does not formally conduct technology assessment processes it makes 
preclinical evaluations, studies of safety and efficacy reported by manufacturers of new technologies [10].

The need to transmit out the evaluation of technologies arose in Canada in 1970. [11]. The Canadian health system has been affected by the rapid development of new technologies and greater receptivity and enthusiasm for its adoption. That is why the Canadian model has faced three major pressures in decision-making related to technology coverage [12]: rapid development of new technologies, the demand for technologies of all types, and the fact that some medical specialties promote the use of technologies. That is why in 1989, provincial and territorial governments established the Canadian Coordinating Office for Health Technology Assessment (CCOHTA). CADTH adopted its new name in April 2006 to better reflect its expanded mandate and the broader range of services and products it now offers to support informed decisions on health technologies throughout Canada.

In Latin-American, the role of the Regional Network of Health Technology Assessments for the Americas (RedETSA) (2011) is highlighted. The network aims to promote and strengthen HTA through regional exchanges of information to support decision-making on regulation, use and replacement of technologies, improvements in the quality of care and rational use of technologies, and contribute to the sustainability and equity in access to health systems. Over the years, RedETSA has been playing a key role in the development of HTA in the Region. Currently, RedETSA is represented by 14 countries and 28 institutions. [13].

In Argentina in the 1990s, a group of health professionals set up a master's degree in Clinical Effectiveness at the Faculty of Medicine of the University of Buenos Aires (UBA). In 2013, the Department of Institute for Evaluation of Clinical Effectiveness-IECS, was named an HTA partner, and currently has a rating agency independent health technology, which is a member of the INAHTA (The International Network of Agencies for Health Technology Assessment) and the RedETSA. Additionally, in Argentina there is the Coordinating Unit for Evaluation and Execution of Health Technologies (UCEETS). In order to ensure that all citizens have access to a quality, equitable and efficient health service, since September 2012, UCEETS has broadened its scope by being part of the Public Argentina Network for the Evaluation of Sanitary Technologies (RedARETS) [14].

In Brazil in April 28, 2011, was published the Federal Law 12,401 which provides for the therapeutic care and the incorporation of health technologies within the Brazilian Public Health System (SUS). This law is a milestone for the SUS as it creates the National Committee for Health Technology Incorporation (CONITEC) and defines the criteria and deadlines for technology incorporation in the public health system. The Committee is responsible for advising the Brazilian Ministry of Health in the incorporation or disinvestment of health technologies into the SUS and development of clinical guidelines [15].

In Chile, in 1997 Ministry of Health installed an HTA Unit, which in 2009 and through Resolution No. 806, were formally incorporated into the Department of Quality and Patient Safety. This unit, which was affiliated to the INAHTA, has the function of generating reports on the review of evidence and services of interest to the health authority. The unit, whose first step is the making of coverage decisions, ceased to function in 2010 [16]. Subsequently, in order to respond to this need, the National HTA Commission is created (2012) [17]. Currently, Chile works in the constant development of HTA Reports and their diffusion, in the generation of competences in the development of HTA within the Ministry of Health and also in the health care network [18].

In México, in January 2014, was created CENETEC (National Center Excellence Technology in Health). This center responded to the need of the health system to have systematic, objective and based on the best available evidence information about management and appropriate use of health technologies. This is a body of the Ministry of Health. In 2009, it was named as the WHO Collaborating Center. This center publishes documents describing the process and methods to be followed in HT [19].

In Colombia, according to Law 1438 of 2011, the Institute of Technological Evaluation in Health was born. This is a non-profit corporation, with mixed participation and private character. The objective is to carry out the evaluation of health technologies based on scientific evidence and to produce guidelines and protocols to recommend to the competent authorities the technologies that must be covered with public resources. Through the General System of Social Security in Health. by Decree 1011 of 2006 [20] establishes four components: Single Habilitation System, Quality Improvement Audit, Single Accreditation System And Quality Information System. The first component, currently governed by resolution 2003 of 2014 [21] clearly indicates the obligation of health institutions to have processes for the management of medical devices, in terms of the selection, acquisition, transportation, reception, storage, among others.

Institutions traditionally have focused on HTA for incorporation in the public health system. Nevertheless the HTA has started to use as a tool in the acquisition of technology in Hospitals. Kidholm Kristian, et al., 2015 
[22] show the results of an interview study with European hospital managers about their need for information when deciding about investments in new treatment. The overall objective of this study was to strengthen the use and impact of HTA in hospitals. This study is framed within the project AdHopHTA (Adopting Hospital Based Health Technology Assessment in EU) which brings together 10 partners from nine different countries: six hospitals with HTA programs (Spain, Denmark, Finland, Switzerland, Italy, Turkey); one hospital without a HTA program (Estonia); two national HTA agencies (Norway and Austria); and one business school (Spain) [22]

Another study, Boudard and colleagues [23] mention that a problem for the hospital decision makers is the lack of clinical evidence to evaluate the efficacy of medical devices. They found only 47 (22\%) of a total of 215 clinical studies provided high-level clinical evidence and $33(15 \%)$ were randomized controlled trials (RCTs). More than half of the 215 studies (52.1\%) included fewer than 30 patients. This finding may suggest the weakness on the regulations established in the European Union, and in the US by the FDA, regarding the guidelines that allow a manufacturer to present clinical studies of equivalent devices to be marketed, this leads to not knowing if the Devices are safe and effective.

With the aim of contributing to the acquisition process of technology in hospitals, this study made the literature review with the purpose of identifying the recommended attributes in HTA by different institutions (agencies) dedicated to the HTA in different countries.

\section{Methodology}

The first step was the identification of the countries and institutions that perform HTA by mean of the countries members of INAHTA list and the scientific articles focused in the identification of institutions, revision of characteristics and methodologies for HTA in hospitals. [22], [24]. Finally the opinion of the experts was consulted to adjust the final list.

The second step consisted of examining each of the countries and institutions with the purpose of finding guidelines, protocols, check lists and other documents that described the attributes used in HTA. The documents found and available in the Web can be consulted using the link presented in the Table 1.

The selected 13 documents were classified according to the types of technology (devices, medicines, treatments and procedures) to which they were addressed. Concluding with $77 \%(\mathrm{n}=10$ documents $)$ that for the most part these documents are aimed at all types of technologies. 8\% ( $\mathrm{n}=1$ documents) were focused on medical devices and $15 \%(\mathrm{n}=2$ documents $)$ are exclusively for diagnostic technologies.

The third step was carried out by identifying the attributes of HTA pointed out in the documents. Finally, these attributes were classified or grouped according to the similarities of the characteristics of each of them.

\section{RESULTS}

The review identified a total of 21 documents from nine countries (Austria, Brazil, Canada, Colombia, Denmark, Spain, France, the Netherlands and the United Kingdom). Their relevance were assessed and eight documents were discarded (Fig. 1).

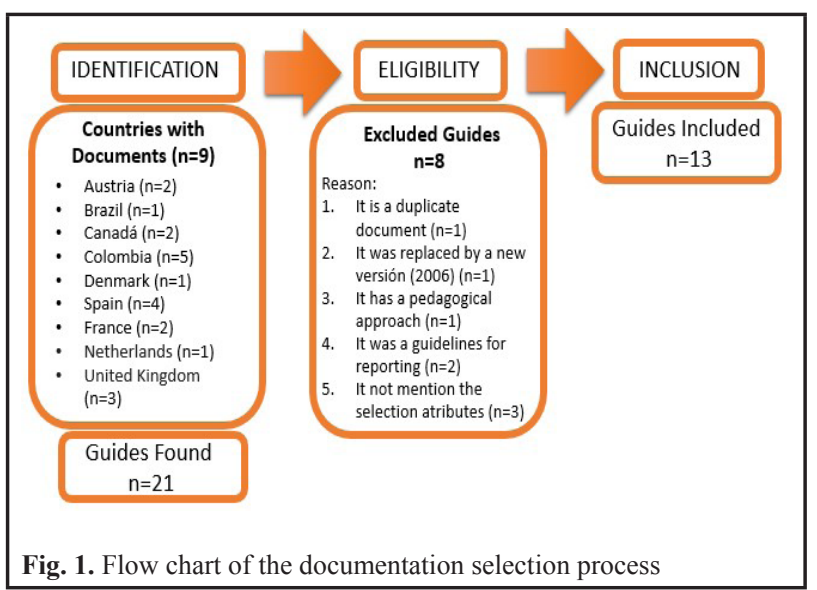

The scope of application was classified by: applied to hospital, health system and unspecified. For the hospitals, $69 \%$ ( $\mathrm{n}=9$ documents) were obtained, which are responsible for assessing aspects such as safety, efficacy and effectiveness of health care technologies, as well as, the resources necessary to provide the technology, and the costs and consequences of providing such technology.

For health system were obtained 23\% ( $\mathrm{n}=3$ documents), which are responsible for providing guidelines to HTA for the incorporation, modification or exclusion of technology at different levels of management. The different institutions, center developers of evaluation of technologies and external groups support the rigorous execution of the basic requirements that a report of evaluation of effectiveness, safety and diagnostic validity.

Eight percent of the documents $(\mathrm{n}=1)$ did not specify the scope of application. This document was the manual for the elaboration of economic evaluations of Colombia. [Table 2] 
Table 1. List of countries and documents about HTA attributes

\begin{tabular}{|c|c|c|c|c|}
\hline DOCUMENT & COUNTRY & $\begin{array}{l}\text { AGENCY OR } \\
\text { INSTITUTION }\end{array}$ & $\begin{array}{l}\text { TYPE OF } \\
\text { INSTITUTION }\end{array}$ & LINK \\
\hline $\begin{array}{l}\text { Evaluation of diagnostic } \\
\text { technologies: background, problems } \\
\text { and methods }\end{array}$ & Austria & $\begin{array}{l}\text { LBI ( Ludwing } \\
\text { Boltzmann Institut) }\end{array}$ & $\begin{array}{l}\text { Independent research } \\
\text { entities with role } \\
\text { as governmental } \\
\text { institution }\end{array}$ & http://eprints.hta.lbg.ac.at/898/1/HTA-Projektbericht_Nr36.pdf \\
\hline $\begin{array}{l}\text { Elaboration of studies for the } \\
\text { evaluation of medical assistance } \\
\text { equipment }\end{array}$ & Brazil & Ministry of Health & $\begin{array}{l}\text { Government } \\
\text { Institution }\end{array}$ & $\begin{array}{c}\text { http://portalsaude.saude.gov.br/images/pdf/2014/ } \\
\text { novembro/10/D iretrizes-metodologicas-avaliacao-de- } \\
\text { equipamento-medico- } \\
\text { assistenciais-cienciasus.pdf }\end{array}$ \\
\hline $\begin{array}{l}\text { Guidelines for the economic } \\
\text { evaluation of health technologies }\end{array}$ & \multirow{2}{*}{ Canada } & $\begin{array}{l}\text { CADTH(Canadian } \\
\text { agency for drugs and } \\
\text { technologies in health) }\end{array}$ & $\begin{array}{l}\text { Independent research } \\
\text { entities with role } \\
\text { as governmental } \\
\text { institution }\end{array}$ & $\begin{array}{c}\text { https://www.cadth.ca/media/pdf/186_EconomicGuidelines_e. } \\
\text { pdf }\end{array}$ \\
\hline $\begin{array}{l}\text { A guide for health technology } \\
\text { assessment in the palliser health } \\
\text { region }\end{array}$ & & $\begin{array}{l}\text { AHFMR (Alberta } \\
\text { heritage foundation } \\
\text { for medical research) }\end{array}$ & $\begin{array}{l}\text { Independent research } \\
\text { entities }\end{array}$ & $\begin{array}{l}\text { http://www.ihe.ca/publications/a-guide-to-health- } \\
\text { technologyassessment-in-the-palliser-health-region }\end{array}$ \\
\hline $\begin{array}{l}\text { Manual for the elaboration of } \\
\text { evaluations of effectiveness, safety } \\
\text { and validity diagnosis of health }\end{array}$ & \multirow{3}{*}{ Colombia } & \multirow{3}{*}{$\begin{array}{l}\text { IETS (Institute of } \\
\text { evaluation of } \\
\text { technologies in health }\end{array}$} & \multirow{3}{*}{$\begin{array}{l}\text { Independent research } \\
\text { entities with role } \\
\text { as governmental } \\
\text { institution }\end{array}$} & $\begin{array}{l}\text { http://www.iets.org.co/Manuales/Manuales/Manual } \% 20 \\
\text { EyS } \% 20 \% 20 \text { web_30\%20sep.pdf }\end{array}$ \\
\hline $\begin{array}{l}\text { Manual for the elaboration of } \\
\text { economic health assessments }\end{array}$ & & & & $\begin{array}{c}\text { http://www.iets.org.co/manuales/Manuales/Manual } \% 20 \\
\text { evaluacio } \% \text { CC } \% 81 \text { n } \% 20 \text { econo } \% \text { CC } \% 81 \text { mica } \% 20 \text { web } \% 20 \\
30 \% 20 \text { sep.pdf }\end{array}$ \\
\hline $\begin{array}{l}\text { Guide methodology for the conduct } \\
\text { of economic evaluations in the } \\
\text { framework of clinical practice } \\
\text { guidelines }\end{array}$ & & & & 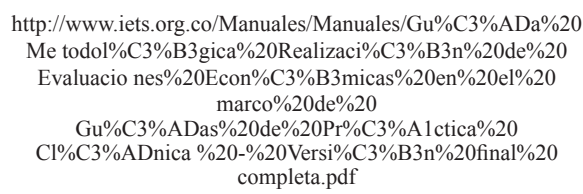 \\
\hline $\begin{array}{l}\text { Introduction to mini-hta: a } \\
\text { management and decision support } \\
\text { tool } \\
\text { for hospital service }\end{array}$ & Denmark & $\begin{array}{l}\text { DACEHTA (Danish } \\
\text { health autority) }\end{array}$ & $\begin{array}{l}\text { Independent research } \\
\text { entities with role } \\
\text { as governmental } \\
\text { institution }\end{array}$ & http://vortal.htai.org/?q=node/207 \\
\hline $\begin{array}{l}\text { Update of the guide to the } \\
\text { acquisition of new technologies }\end{array}$ & Spain & $\begin{array}{l}\text { AETSA (Agency for } \\
\text { evaluation of sanitary } \\
\text { technologies of } \\
\text { andalusia) }\end{array}$ & $\begin{array}{c}\text { Government } \\
\text { Institution }\end{array}$ & $\begin{array}{l}\text { http://www.juntadeandalucia.es/export/ } \\
\text { drupaljda/1337163008act ualizacion_gant.pdf }\end{array}$ \\
\hline $\begin{array}{l}\text { Methodological choices for the } \\
\text { clinical development of medical } \\
\text { devices }\end{array}$ & France & $\begin{array}{l}\text { HAS (National health } \\
\text { authority) }\end{array}$ & $\begin{array}{c}\text { Government } \\
\text { Institution }\end{array}$ & $\begin{array}{l}\text { http://www.has- } \\
\text { sante.fr/portail/upload/docs/application/pdf/2014- } \\
\text { 03/methodological_choices_for_the_clinical_development_of } \\
\text { medical_devices.pdf }\end{array}$ \\
\hline $\begin{array}{l}\text { Medical tests (assessment of } \\
\text { established medical science and } \\
\text { medical practice) }\end{array}$ & Netherlands & $\mathrm{ZIN}$ & $\begin{array}{l}\text { Independent research } \\
\text { entities with role } \\
\text { as governmental } \\
\text { institution }\end{array}$ & $\begin{array}{l}\text { https://www.zorginstituutnederland.nl/binaries/content/ } \\
\text { document s/zinl-www/documenten/publicaties/publications- } \\
\text { inenglish/2011/1101-medical-tests-assessment-of- } \\
\text { establishedmedical-science-and-medical- } \\
\text { practice/Medical+tests+(assessment+of+established+medica } \\
\quad \text { +sci } \\
\text { ence+and+medical+practice).pdf }\end{array}$ \\
\hline $\begin{array}{l}\text { Medical technologies evaluation } \\
\text { programme (process guide) }\end{array}$ & & & $\begin{array}{l}\text { Government } \\
\text { Institution }\end{array}$ & $\begin{array}{l}\text { https://www.nice.org.uk/Media/Default/About/what-we-do/ } \\
\text { NICEguidance/NICE-medical-technologies/Medical- } \\
\text { technologies- } \\
\text { evaluation-programme-process-guide.pdf }\end{array}$ \\
\hline $\begin{array}{l}\text { Medical technologies evaluation } \\
\text { prijogramme (methods guide) }\end{array}$ & kingdom & & $\begin{array}{l}\text { Government } \\
\text { Institution }\end{array}$ & $\begin{array}{l}\text { https://www.nice.org.uk/Media/Default/About/what-we-do/ } \\
\text { NICEguidance/NICE-medical-technologies/Medical- } \\
\text { technologies- } \\
\text { evaluation-programme-methods-guide.pdf }\end{array}$ \\
\hline Does not have a guidebook & Argentina & IECS & $\begin{array}{l}\text { Institute for } \\
\text { Evauation of Clinical } \\
\text { Effectiveness }\end{array}$ & N/A \\
\hline Does not have a guidebook & México & CENETEC & $\begin{array}{l}\text { National Center for } \\
\text { technological } \\
\text { Excellence in Health }\end{array}$ & N/A \\
\hline Does not have a guidebook & Chile & Ministerio de Salud & Ministry of Health & $\mathrm{N} / \mathrm{A}$ \\
\hline
\end{tabular}


Table 2. Overview of information about role and scope of included institutions

\begin{tabular}{cc}
\hline Characteristics & Institutions (n=13) (\%) \\
\hline \multicolumn{2}{c}{ Types of technologies } \\
\hline All types of technology & $10(77 \%)$ \\
Medical devices & $1(8 \%)$ \\
Technologies for diagnosis & $2(15 \%)$ \\
\hline Scope of Application of documents \\
\hline Hospitals & $9(69 \%)$ \\
Health System & $3(23 \%)$ \\
Not Specified & $1(8 \%)$ \\
\hline The attributes of health technology assessment & $12(92 \%)$ \\
Clinical & $10(77 \%)$ \\
Economic & $8(62 \%)$ \\
Social and Ethical & $7(54 \%)$ \\
Operational Technician & $6(46 \%)$ \\
Organizational & $4(31 \%)$ \\
Innovation & $3(23 \%)$ \\
Admissibility &
\end{tabular}

Seven different attributes were identified in the 13 documents, and are described below:

\section{Clinical Attributes}

This attribute is related with the search of scientific evidence to demonstrate the efficacy and safety of the technology. It is pertinent to include the impact of the adverse events associated with the technology and determine which are the benefits for the health, including the way in which the technology will improve the access and safety of the patient or health personnel. These attributes were mentioned in $92.3 \%$ of the documents $(n=12)$.

\section{Economic Attributes}

These consist of comparing the relationship between the social value of the clinical effects of a technology and its respective costs with the corresponding alternatives. Different types of economic analysis were pointed out by the documents, among them are: cost minimization analysis, cost-effectiveness analysis, cost-utility analysis and costbenefit analysis. The first analysis is used when the effectiveness of the alternatives is the same, but the cost is different. The second is used when there is a result of common interest to the considered alternatives, but where the effectiveness of themselves, like the costs, differs. In the third, the health outcomes of the considered alternatives are expressed in terms of utility. In the last one, the costs and the health outcomes of the alternatives are measured in monetary units [29]. It was the second most frequently used attribute in $77 \%(\mathrm{n}=10$ documents $)$.

\section{Social and Ethical Attributes}

It takes into account the coverage and demand in the use of the evaluated technology. It identifies the equity characteristics of the subgroups that can benefit from the new technology. It includes the analysis of the characteristics of the population, such as age, sex, ethnicity, socioeconomic group, geographical area or health status, which may be relevant to equity. This attribute has a frequently of $61.5 \%$ ( $n=8$ documents).

\section{Operational Technician Attributes}

It refers to the detailed analysis of the principle of operation of a medical device, regarding mechanical and electrical safety, the training for the correct use of thistechnology, as well as the need of accessories, supplies, maintenance and adequate storage for the use of this technology.

The documents recommended to carry out a search of different models of technology that must be acquired to perform a comparative analysis. This attribute was mentioned in $54 \%$ of the documents $(\mathrm{n}=7)$.

\section{Organizational Attributes}

This attributes refers to the operating processes and the infrastructure within a health institution. The processes depend on the expertise, training and communication among the work team, work flow, potential barriers for the use; and the structure refers to the physical resources and resources, the diffusion of technology, the system of control and evaluation, the culture and the environment. This attribute was mentioned by $46 \%$ of the documents $(n=6)$.

\section{Innovation Attributes}

This attribute is related to the fact of a technology to be or not to innovation, which could be a radical (such as a new treatment or diagnosis) or an incremental innovation an alternative way to treat or diagnosis a health problem. With advantage for the patient or the health service. This attribute was mentioned in a $31 \%$ of the documents $(n=4)$.

\section{Admissibility Attributes}

It refers to the existing of a technology market regulation (laws, resolutions and decrees) and all types of requirements established by law in the pre and post marketing stage of a technology. This attribute was mentioned of $23 \%$ ( $n=3$ documents). 


\section{Discussion}

This research identified the attributes used for the HTA. Although not all the documents are applied to the hospital HTA, 77\% presented this approach (Austria, Canada, Colombia, Denmark, Spain, France, and United Kingdom). Regarding the type of technology, only the Brazilian document was specific to HTA of medical devices or medical equipment. This could reflect that certain attributes for the evaluation described in a general methodological document are applied to all types of technologies, including the medical devices.

The clinical attribute prevailed in most of the documents, this can be explained because the scientific evidence is a basic principal for HTA and the strongest attribute for decision making. Only one Colombian document focused specifically the economic attribute. The technical operational attribute was approached only in $54 \%$ of the documents. This may be due to the fact that it is specifically for the evaluation of medical devices or medical equipment.

The less mentioned attribute in the documents was the admissibility although it deals with a basic step in the health technology life cycle. It may occurred by the fact that it is a consolidated step in the most of the countries that have a consolidated HTA process in their health system involved in HTA

\section{Conclusion}

This work was able to identify and compare the attributes for HTA based on documents published by HTA agencies inside and outside Latin America to advance the debate on the most used and appropriated attributes can be applied by the local health providers. Whether existing evaluation instruments need to be modified or adapted or if a completely new approach is needed.

A consensus was found regarding the applied attributes in, however the next step will be to explore which of these have already being applied and the practicality of applying them by the Colombian health providers. The nine documents found and directed towards hospitals will serve as a basis for continuing this research.

\section{REFERENCES}

[1]. J. L. C. Olasagasti, «Evaluación de tecnologías médicas basadas en la evidencia,» Ministerio de Sanidad y Consumo. Instituto de Salud Carlos III, Madrid, 1998.
[2]. Evaluación de Tecnologías Sanitarias y establecimiento de prioridades. Evaluación de Tecnologías Sanitarias. Vol 5. №1. Abril 2004.

[3]. L. Stretch, E Amend. A Guide to Health Technology Assessment in the Palliser Health Region, Canada: Health Technology Assessment Unit Alberta Heritage Foundation for Medical Research, 2006.

[4]. D. Banta, E. Jonsson y P. Childs , «History of the international societies in health technology assessment: International Society for technology Assessment in Health Care and Health Technology Assessment International,» International Journal of Technology Assessment in Health Care, vol. 25, pp. 19-23, 2009.

[5]. F. Borlum Kristensen, M. Velasco Garrido, C. Palmhoj Nielsen y R. Busse, Health Technology Assessment and Health PolicyMaking in Europe, WHO; European Observatory on Health Systems and Policies, 2008.

[6]. EunetHTA, «EunetHTA,» Europen Commision, [En línea]. Available: http://eunethta.fedimbo.belgium.be/activities/eunethtajoint-action-201012. [Último acceso: 24 Septiembre 2016].

[7]. Ludwig Boltzmann Gesellschaft, [En línea]. Available: http:// hta.lbg.ac.at/page/leitbild-geschichte/en.

[8]. Agencia de Evaluación de Tecnologias Sanitarias de Andalucia (AETSA), [En línea]. Available: http://www.aetsa.org/quienessomos/. [Último acceso: 14 July 2016].

[9]. NICE, [En línea]. Available: https://www.nice.org.uk. [Último acceso: 14 July 2016].

[10]. S. D. Sullivan, J. Watkins, B. Sweet y S. D. Ramsey, «Health Technology Assessment in Health-Care Decisions in the United States,» Value in Health, vol. 2, n 12, pp. 39-44, 2009.

[11]. M. P., «The National Office for the Evaluation of Medical Technology and Procedures (NOEMTP): A proposal,» de 2nd International Conference in Systems Science in Health Care, Montreal, Canada, 1980.

[12]. S. J. et. al., «Challenges, choices and Canada,» International Journal of Technology Assess Health Care., vol. 18, n 2, pp. 199202, 2002.

[13]. PAHO/WHO Collaborating Centres in HTA, «PAHO/ WHO,» Pan American Health Organization, [En línea]. Available: http://www.paho.org/hq/index. php?option=com_content\&view=article\& id=11598\%3Apahoscurrent-work-on-health-technologyassessment\&catid $=5870 \% 3$ Aassessment\&Itemid=41692\&lang=en. [Último acceso: 16 July 2016].

[14]. IECS, «Instituto de Efectividad Clinica y Sanitaria,» [En línea]. Available: http://www.iecs.org.ar/. [Último acceso: 18 Agosto 2016].

[15]. INAHTA, [En línea]. Available: http://www.inahta.org/members/ conitec/. [Último acceso: 8 December 2016].

[16]. Ministerio de Salud. Resolución Exenta No 806, 2009. Chile.

[17]. Ministerio de Salud. Resolución Exenta No 108, 2012. Chile.

[18]. M. Castillo, L. Kuhn, V. García, M. Espinoza, H. García , B. Freile, P. Flores , M. Delgado y M. G. Rojas, «Propuesta de un modelo de implementación e institucionalización de la Evaluación de Tecnologías Sanitarias en Chile,» Ministerio de Salud, Santiago, Chile, 2013.

[19]. Centro Nacional de Excelencia en Salud, «Programa de Acción Especifico Evaluación y Gestión de Tecnologías para la Salud,» 
Secretaria de Salud, 2013-2018. Dirección general de Información en salud. México.

[20]. Instituto de Evaluación de Tecnologías en Salud, «IETS,» [En línea]. Available: http://www.iets.org.co/quienes-somos/Paginas/ Qu\%C3\%A9es-el-IETS.aspx. [Último acceso: 26 Septiembre 2016].

[21]. Ministerio de Salud. Resolución No. 2003, 2014. Colombia.

[22]. Kidholm Kristian, et al «Hospital managers'need for information in decision-making-An interviw study in nine European countries,» Health Policy, vol. 119, n 11, pp. 1424--1432, 2015.

[23]. N. M. e. a. A. Boudard, «Clinical studies of innovative medical devices: what level of evidence for hospital-based health technology assessment?,» Journal of Evaluation in Clinical Practice, vol. 19, nº 4, pp. 697-702, 2013.

[24]. S. Fuchs, B. Olberg, D. Panteli y R. Busse, «Health Technology Assessemet of Medical devices in Europe: Processes, Practices and methods,» International Journal of Technology Assessment in Health Care, vol. 32, $\mathrm{n}^{\mathrm{o}}$ 4, pp. 1-10, 2016. 